Military Technical College Kobry El-Kobbah, Cairo, Egypt

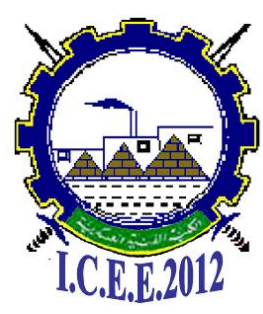

$6^{\text {th }}$ International Conference on

Chemical \& Environmental Engineering 29 -31 May, 2012.

\title{
ENMC-4
}

\section{PREPARATION AND CHARACTERIZATION OF DEMILITARIZED HIGH EXPLOSIVES IN W/O EMULSION EXPLOSIVES.}

\author{
Ondřej Němec ${ }^{*}$, Marcela Jungová*, Adéla Husarová*, Svatopluk Zeman*
}

\begin{abstract}
The present paper summarizes the results of the preliminary research conducted at the Institute of Energetic Materials, the University of Pardubice into the use of demilitarized energetic materials (TNT, RDX) in modification of the W/O emulsion explosives in the framework of grant project of MPO ČR No. FR-TI2/639. It describes the preparation of the emulsion explosives used, some physico-chemical parameters of demilitarized explosives and detonation parameters of the demilitarized and emulsion explosives mixtures. The results of study of certain mixtures containing no micro-balloons show that they have similar characteristics as the amatols and several dynamites. Incorporating of demilitarized explosives into the mixtures with emulsion explosives can be a solution to their health and environmental problems.
\end{abstract}

Institute of Energetic Materials, University of Pardubice, Studentská 95, 53210 Pardubice, The Czech Republic

phone ++420 466038 026, fax ++420 466038023 ,

e-mail marcela.jungova@upce.cz 


\section{Introduction}

The emulsion high explosives of the water-in-oil type belong to the most widespread industrial explosives. They are favored due to their good performance parameters and exceptionally good safety parameters. A major drawback of emulsion high explosives is their insensitivity to shock wave, i.e. difficult initiation of these explosives. Hence the emulsion explosives have to be sensitized by addition of suitable sensitizer, such as, e.g., small glass or polymeric hollow spheres (micro-balloons), which introduce gas into the mixture or brisant explosive. In principle, an emulsion high explosive is a mixture of two immiscible liquids, in which one liquid is composed of a mixture of oxidizers and the other is a mixture of fuels. The mixture of oxidizers in liquid state is dispersed in the fuel in the form of droplets having the size below ca $10 \mu \mathrm{m}$. The emulsion thus produced is not stable: the droplets of dispersed oxidizer mixture can undergo agglomeration and/or recrystallization. Both these phenomena result in reduction of inter-phase surface with concomitant lowering of performance parameters of emulsion high explosives. These undesirable phenomena are suppressed by addition of emulsifiers, such as sorbite mono-stearate or mono-oleate, polymeric emulsifiers based on polyisobutylene etc. [Apolenis 2006, Kalatsey 1995, Maranda 2002, Mendoca 1996 and 1997, Zeman 2004 and 2005, Xuguang 1994, Zeman \& Tamchyna, 2004 and 2005].

Applications of demilitarized high explosives are relatively restricted. Their direct use in blasting operations is unsuitable due to low detonation parameters and health-ecological problems. Chemical reprocessing to products of higher value is not frequent and tends to be very expensive. Demilitarized high explosives can contain impurities of polymeric nature (waxes, lacquers, paints used during filling into ammunition as internal protective coating); they exist in a variety of shapes, e.g., powders, cylinders, flakes. All these facts can affect their detonation parameters. Earlier research showed that a satisfactory sensitizing of emulsion high explosive can be achieved by addition of $30 \% \mathrm{w} / \mathrm{w}$ of brisant high explosive or multi-perforated propellants. The use of demilitarized high explosives of TNT and RDX types in their original quality (without previous modification) for sensitizing emulsion explosives without the necessary addition of microbaloons has been reported in literature quite insufficiently so far [Kohlicek, 2000 and 2001; Zeman 2003, Apolenis 2006, Kalatsey 1995, Maranda 2002, Mendoca 1996 and 1997, Zeman 2004 and 2005, Xuguang 1994].

\section{Experimental}

The emulsion matrix was prepared in a simple apparatus composed of a stirrer, container and thermostat. The solution of oxidizers was kept at the temperature of $95-100{ }^{\circ} \mathrm{C}$, whereupon it was slowly added into preheated ( $\mathrm{ca} 90^{\circ} \mathrm{C}$ ) solution of fuels and emulsifier with intensive stirring (2000 rpm). The obtained emulsion was stirred further for ca $2 \mathrm{~min}$ in order to achieve better distribution of particles. The composition of prepared emulsion matrices is presented in Table 1.

Ammonium nitrate, sodium nitrate and grounds (slack wax) were obtained from the comp. Explosia a.s. Calcium nitrate (under the name Lovoferit) was obtained from the comp. Lovochemie a.s., and the adopted oil from the comp. Lavat a.s. The emulsifier adopted was Anfomul S6 (sorbite mono-isostearate). All the demilitarized high explosives used were obtained from the comp. Poličské strojírny a.s. and were not purified or modified in any way except for sieving. The used demilitarized explosive on the basis of pure TNT was ground Politol, that based on TNT plus RDX (50/50) was ground Composition B. The grain size of Politol was in the range from $50 \mu \mathrm{m}$ to $4 \mathrm{~mm}$. Composition B was finely ground and contained $94 \% \mathrm{w} / \mathrm{w}$ of grain size fraction below $2 \mathrm{~mm}$ and $74 \% \mathrm{w} / \mathrm{w}$ of grain size fraction below $1 \mathrm{~mm}$. Politol was submitted to sieving to give several fractions (see Table 2). The final mixtures of emulsion and demilitarized explosives were prepared by manual mixing of the 
two components. Selected parameters were compared with those of some commercially manufactured (in Explosia a.s. comp.) high explosives (see Table 3).

Table 1: Composition of adopted emulsions A and B

\begin{tabular}{l|rr}
\hline Emulsion & \multicolumn{2}{|c}{ A } \\
Component & \multicolumn{2}{|c}{$\%$ w/w } \\
\hline AN & 72 & 42.8 \\
SN & 9.6 & 0 \\
CN & 0 & 31.4 \\
Water & 11 & 19.8 \\
Oil & 2.2 & 4 \\
Grounds & 2.2 & 0 \\
Emulsifier & 3 & 2 \\
\hline
\end{tabular}

Table 2: Survey of adopted Politol fractions

\begin{tabular}{lccccc}
\hline Fraction no. & $\mathbf{1}$ & $\mathbf{2}$ & $\mathbf{3}$ & $\mathbf{4}$ & $\mathbf{5}$ \\
\hline Grain size $(\mu \mathrm{m})$ & $<100$ & $<200$ & $100-200$ & $200-400$ & $400-800$ \\
\hline \hline Fraction no. & $\mathbf{6}$ & $\mathbf{7}$ & $\mathbf{8}$ & $\mathbf{9}$ & $\mathbf{1 0}$ \\
\hline Grain size $(\mu \mathrm{m})$ & $800-600$ & $1000-000$ & $1600-4000$ & $>4000$ & No sieving \\
\hline
\end{tabular}

Table 3: Survey of commercially available high explosives manufactured by Explosia a.s.

\begin{tabular}{|c|c|c|c|c|c|c|}
\hline \multicolumn{3}{|c|}{ Commercial high explosive } & \multirow{2}{*}{$\begin{array}{c}\text { Nitro ester } \\
\text { content } \\
(\% \mathrm{w} / \mathrm{w}) \\
\end{array}$} & \multirow{2}{*}{$\begin{array}{c}\text { Detonation } \\
\text { velocity } \\
\left(\mathrm{m} \mathrm{s}^{-1}\right)\end{array}$} & \multirow{2}{*}{$\begin{array}{l}\text { Density } \\
\left(\mathrm{g} \mathrm{cm}^{-3}\right)\end{array}$} & \multirow{2}{*}{$\begin{array}{c}\mathrm{RS} \\
(\% \mathrm{BG})\end{array}$} \\
\hline Trade mark & Type & Application & & & & \\
\hline Emsit $\mathrm{M}$ & Emulsion & Mining & 0 & 5100 & 1.05 & 63 \\
\hline Infernit 45 & $\begin{array}{l}\text { Gelatin- } \\
\text { ized }\end{array}$ & Special & & 6400 & 1.45 & 70 \\
\hline Ostravit C & $\begin{array}{c}\text { Semi- } \\
\text { gelatinize } \\
\mathrm{d}\end{array}$ & $\begin{array}{l}\text { Safe for } \\
\text { mining }\end{array}$ & 11 & 1900 & 1.20 & 40 \\
\hline Perunit E & $\begin{array}{l}\text { Gelatin- } \\
\text { ized }\end{array}$ & Mining & 22 & 6000 & 1.38 & 78 \\
\hline Permon 10T & Amatol & Mining & 0 & 4000 & 1.05 & 89 \\
\hline Permonex V 19 & Amatol & Mining & 0 & 4400 & 1.05 & 91 \\
\hline Semtex $1 \mathrm{~A}$ & Plastic & Special & $84(\mathrm{PETN})$ & 7400 & 1.47 & 80 \\
\hline Semtinit 50 & $\begin{array}{l}\text { Gelatin- } \\
\text { ized }\end{array}$ & $\begin{array}{c}\text { Safe for } \\
\text { mining }\end{array}$ & 25 & 2280 & 1.50 & 34 \\
\hline
\end{tabular}




\subsection{Measurements of Detonation Velociti}

The detonation velocities were measured in cylindrical charges of 37 or $60 \mathrm{~mm}$ diameter in polyethylene (PE) wrapping. The adopted actuator was $20 \mathrm{~g}$ high explosive Semtex 1A with $0-\mathrm{S}$ detonator, Al cylindrical case (initiation power $\sim$ no. 8 ). The charges were placed in sand - the maximum depth was $20 \mathrm{~cm}$. The measurement was performed by means of an Explomet-fo-2000 apparatus (from Kontigro comp.) with three optical sensors. The distance of the first sensor from the actuator was at least $15 \mathrm{~cm}$, the distances between the sensors being at least $10 \mathrm{~cm}$. The data measured with pure emulsions are given in Table 4, those measured with the mixture of emulsion matrix A and Politol (50/50) are given in Table 5, and those measured with mixtures of emulsion matrices A and B and Composition B (in various proportions) are given in Table 6.

Table 4: Measured detonation velocities of emulsions A and B sensitized with $3 \% \mathrm{w} / \mathrm{w}$ of micro-balloons

\begin{tabular}{ccc}
\hline Emulsion & $\begin{array}{c}\text { Detonation velocity } \\
\left(\mathrm{m} . \mathrm{s}^{-1}\right)\end{array}$ & $\begin{array}{c}\text { Charge density } \\
\left(\mathrm{g} \cdot \mathrm{cm}^{-3}\right)\end{array}$ \\
\hline $\mathrm{A}$ & 5160 & 1.13 \\
$\mathrm{~B}$ & 3900 & 1.17 \\
\hline
\end{tabular}

Table 5: Measured detonation velocities of mixtures of Emulsion A and Politol in 50/50 proportion with various grain sizes of Politol

\begin{tabular}{|c|c|c|c|c|c|c|c|}
\hline $\begin{array}{c}\text { Fraction } \\
\text { no. }\end{array}$ & $\begin{array}{l}\text { Politol } \\
\text { grain size }\end{array}$ & $\begin{array}{l}\text { Charge } \\
\text { density } \\
\left(\mathrm{g} . \mathrm{cm}^{-3}\right)\end{array}$ & $\begin{array}{c}\text { Detonation } \\
\text { velocity } \\
\left(\mathrm{m} \cdot \mathrm{s}^{-1}\right)\end{array}$ & $\begin{array}{c}\text { Fraction } \\
\text { no. }\end{array}$ & $\begin{array}{l}\text { Politol } \\
\text { grain size }\end{array}$ & 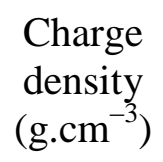 & $\begin{array}{c}\text { Detonation } \\
\text { velocity } \\
\left(\mathrm{m} . \mathrm{s}^{-1}\right)\end{array}$ \\
\hline 1 & $<100 \mu \mathrm{m}$ & 1.43 & 6053 & 7.1 & $1-2 \mathrm{~mm}$ & 1.47 & 5679 \\
\hline 2 & $<200 \mu \mathrm{m}$ & 1.45 & 5948 & 7.2 & $1-2 \mathrm{~mm}$ & 1.52 & 5705 \\
\hline 3 & $100-200 \mu \mathrm{m}$ & 1.45 & 5797 & 8.1 & $1.6-4 \mathrm{~mm}$ & 1.4 & 5452 \\
\hline 4.1 & $200-400 \mu \mathrm{m}$ & 1.42 & 5887 & 8.2 & $1.6-4 \mathrm{~mm}$ & 1.39 & 5330 \\
\hline 4.2 & $200-400 \mu \mathrm{m}$ & 1.41 & 5935 & 8.3 & $1.6-4 \mathrm{~mm}$ & 1.43 & 5492 \\
\hline 5.1 & $400-800 \mu \mathrm{m}$ & 1.39 & 5727 & 9.1 & $>4 \mathrm{~mm}$ & 1.4 & 5549 \\
\hline 5.2 & $400-800 \mu \mathrm{m}$ & 1.45 & 5712 & 9.2 & $>4 \mathrm{~mm}$ & 1.48 & 5809 \\
\hline 6.1 & $\begin{array}{c}800-1600 \\
\mu \mathrm{m}\end{array}$ & 1.43 & 5697 & 10.1 & $\begin{array}{l}\text { original } \\
\text { Politol }\end{array}$ & 1.41 & 5562 \\
\hline 6.2 & $\begin{array}{c}800-1600 \\
\mu \mathrm{m}\end{array}$ & 1.47 & 5687 & 10.2 & $\begin{array}{c}\text { original } \\
\text { Politol }\end{array}$ & 1.4 & 5657 \\
\hline
\end{tabular}


Table 6: Measured detonation velocities of mixtures of emulsions A and B with demilitarized Composition B

\begin{tabular}{|c|c|c|c|c|c|c|c|}
\hline $\begin{array}{c}\text { Compositi } \\
\text { on }\end{array}$ & $\begin{array}{c}\text { Detonation } \\
\text { velocity } \\
\left(\mathrm{m} \mathrm{s}^{-1}\right)\end{array}$ & $\begin{array}{c}\rho \\
\left(\mathrm{g} \mathrm{cm}^{-3}\right)\end{array}$ & $\begin{array}{c}\rho D^{2} \\
(\mathrm{GPa})\end{array}$ & $\begin{array}{c}\text { Compositi } \\
\text { on }\end{array}$ & $\begin{array}{c}\text { Detonation } \\
\text { velocity } \\
\left(\mathrm{m} \mathrm{s}^{-1}\right)\end{array}$ & $\begin{array}{c}\rho \\
\left(\mathrm{g} \mathrm{cm}^{-3}\right)\end{array}$ & $\begin{array}{c}\rho D^{2} \\
(\mathrm{GPa})\end{array}$ \\
\hline $70 \%$ & & & & $60 \%$ & & & \\
\hline Emulsion & & & & Emulsion & & & \\
\hline$A+30 \%$ & 5559 & 1.45 & 44.8 & $B+40 \%$ & 6005 & 1.48 & 53.4 \\
\hline $\begin{array}{c}\text { Compositi } \\
\text { on } \mathrm{B}\end{array}$ & & & & $\begin{array}{c}\text { Compositi } \\
\text { on B }\end{array}$ & & & \\
\hline $65 \%$ & & & & $50 \%$ & & & \\
\hline Emulsion & & & & Emulsion & & & \\
\hline $\mathrm{A}+35 \%$ & 5932 & 1.46 & 51.4 & $\mathrm{~B}+50 \%$ & 6465 & 1.49 & 62.3 \\
\hline $\begin{array}{c}\text { Compositi } \\
\text { on } \mathrm{B}\end{array}$ & & & & $\begin{array}{c}\text { Compositi } \\
\text { on } \mathrm{B}\end{array}$ & & & \\
\hline $60 \%$ & & & & $40 \%$ & & & \\
\hline Emulsion & & & & Emulsion & & & \\
\hline$A+40 \%$ & 6189 & 1.47 & 56.3 & $B+60 \%$ & 6772 & 1.51 & 69.2 \\
\hline $\begin{array}{c}\text { Compositi } \\
\text { on } \mathrm{B}\end{array}$ & & & & $\begin{array}{c}\text { Compositi } \\
\text { on B }\end{array}$ & & & \\
\hline $55 \%$ & & & & & & & \\
\hline Emulsion & & & & & & & \\
\hline$A+45 \%$ & 6449 & 1.48 & 61.6 & & & & \\
\hline $\begin{array}{c}\text { Compositi } \\
\text { on } \mathrm{B}\end{array}$ & & & & & & & \\
\hline $50 \%$ & & & & & & & \\
\hline Emulsion & & & & & & & \\
\hline $\mathrm{A}+50 \%$ & 6749 & 1.49 & 67.9 & & & & \\
\hline $\begin{array}{c}\text { Compositi } \\
\text { on } \mathrm{B}\end{array}$ & & & & & & & \\
\hline
\end{tabular}

\subsection{Measurement of Relative strength (RS)}

The tested high explosive (10 g) was placed in a PE bag and fastened to igniting detonator in the arrangement having the sample at the front and in the axis of the detonator. The sample so arranged with detonator and igniter cord was run through the projectile and then fully inserted into the mortar body. After initiation of sample, the pendulum deflection was read from the scale. The results were compared with the calibration using blasting gelatin (BG). The measured RS values of Emulsion matrix A and its mixtures with Politol and Composition B are summarized in Table 7.

Table 7: Measured RS values of Emulsion A and its mixtures with demilitarized Politol and Composition B in the proportion 50/50

\begin{tabular}{cc}
\hline Composition & RS \\
$(\% \mathrm{BG})$
\end{tabular}




\subsection{Calculations of Detonation Parameters}

The theoretical calculation of detonation parameters was based on European standard EN 13631-15 (Grys and Trzciński 2010a and 2010b). Also the heat of explosion $Q_{v}$, specific force $f$, volume of gases $V_{g}$, explosion temperature $T_{v}$, explosion pressure $P_{v}$, and molar ratio $\mathrm{CO} / \mathrm{CO}_{2}$ in the explosion products were calculated. The values calculated for selected commercial high explosives, pure Emulsion A, and mixtures of Emulsion A with demilitarized high explosives in the proportion of 50/50 are given in Table 8 .

Table 8: Calculated values of some detonation parameters of pure Emulsion A, of mixtures of Emulsion A with brisant demilitarized high explosives and some commercially available high explosives

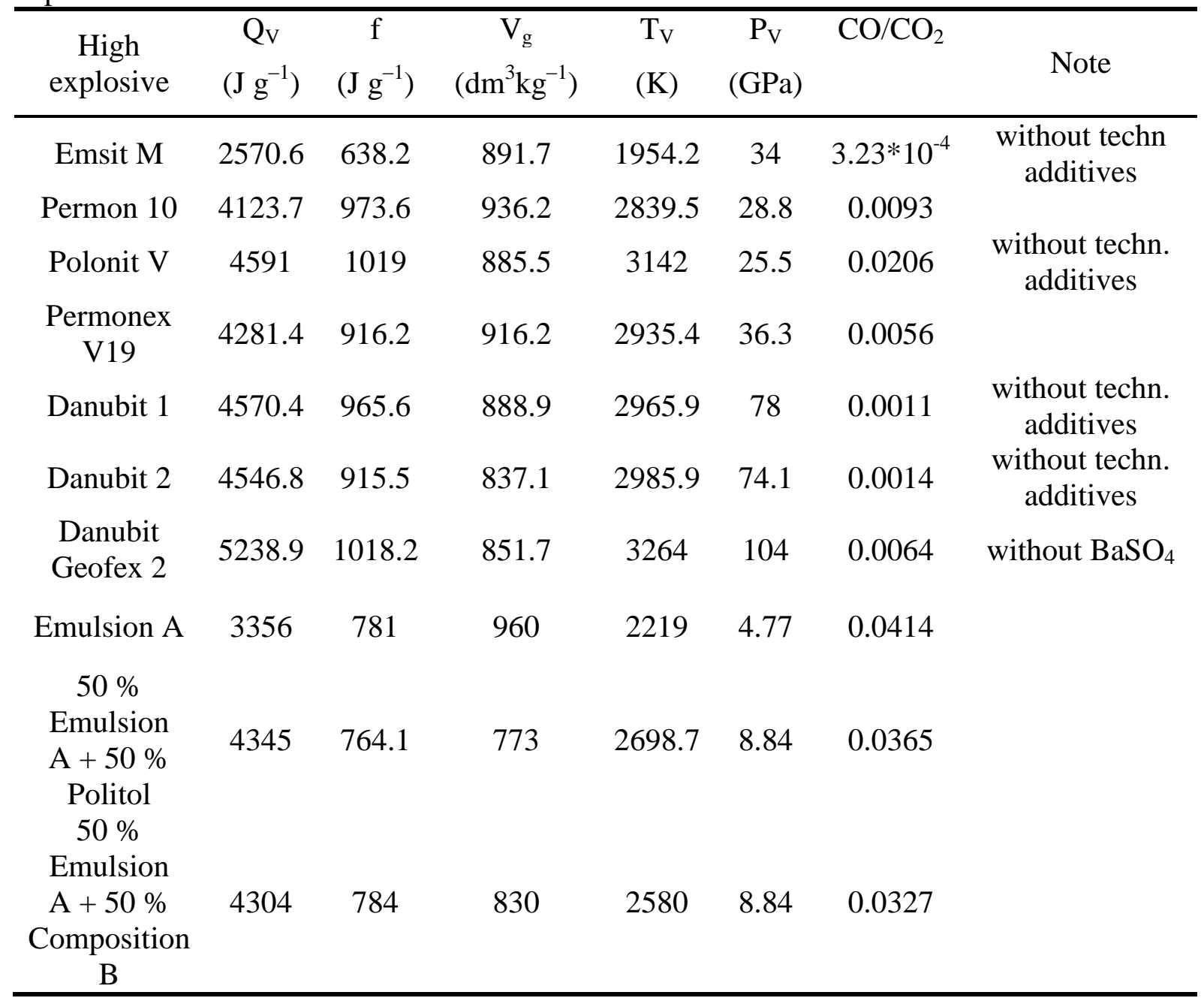

\section{Discussion}

The prepared Emulsion A exhibits a higher detonation velocity than Emulsion B after sensitization with $3 \% \mathrm{w} / \mathrm{w}$ of micro-balloons. The decrease in detonation velocity of emulsion B can be explained by the presence of larger amount of calcium nitrate and water in Emulsion B. The shelf life of pure Emulsion A was at least 5 months, that of pure Emulsion B was 7 months from the day of preparation. In the slurry-type high explosives, the ideal TNT grain size is in the interval of 2-4 mm [Cook 1974]. According to our measurements with high explosives of water-in-oil emulsion type the opposite is true (see Fig. 1). The addition of Politol in the amount of $50 \%$ (with regard to the mass of final high explosive) to Emulsion A increases the density of the mixture from $1.13 \mathrm{~g} . \mathrm{cm}^{-3}$ to ca $1.40 \mathrm{~g} . \mathrm{cm}^{-3}$. 
Fig. 1: Comparison of detonation velocities of mixtures of Emulsion matrix A (Table 5) with Politol of various grain size values (from $50 \mu \mathrm{m}$ to $4000 \mu \mathrm{m}$, Table 2) in 50/50 ratio

Detonation of mixtures of Emulsion A and Politol is not ideal [Němec 2011]. Therefore, these mixtures were found to be less suitable for practical purposes, and attention was focused on mixtures of the emulsions and Composition B. The mixtures of Emulsion A with Composition B have higher densities than those of the mixtures with TNT: about $1.50 \mathrm{~g} . \mathrm{cm}^{-3}$ at the 50/50 ratio of the emulsion and Composition $\mathrm{B}$ in the resulting high explosive. Composition $\mathrm{B}$ was finely ground, which caused considerable separation of hexogen and trinitrotoluene grains during sieving. That is why it was virtually impossible to find the dependence of detonation velocity upon the grain size of Composition B.

The relationship between detonation velocity and content of Composition B in the mixture is presented in Fig. 2. The well-known dependence of detonation velocity on charge density is presented in Fig. 3.

Fig. 2: Dependence of detonation velocity on content of unmodified demilitarized Composition B

Fig. 3: Dependence of detonation velocity on density of mixture of Emulsion A and Composition B

With regard to the linearity of the relationship between detonation velocity and content of Composition $\mathrm{B}$ in the mixture, and the relationship between detonation velocity and charge density, the detonation of these mixtures is closer to ideality than in the case of mixtures of Emulsion A and Politol. Figure 2 shows that a change in content of Composition B in its mixture with Emulsion A can be used to change the detonation parameters within relatively broad limits.

A comparison of performance of the emulsion high explosive fortified in this way with performance values of selected, commercially available high explosives manufactured by comp. Explosia a.s. is presented in Fig. 4.

Fig. 4: Comparison of detonation parameters of commercially available high explosives manufactured by Explosia a.s. comp. with those of pure Emulsion A and mixtures of Emulsion A with brisant demilitarized high explosives

Not only the mixture of Emulsion A with $50 \%$ w/w of demilitarized high explosives based on TNT, but also the Emulsion A alone with sensitization additive of micro-balloons are in their performance abilities approximately at the level of performance values of Permonex V19, Permon 10T and Perunit E.

\section{Conclusion}

An addition of demilitarized TNT as sensitizer to emulsions of W/O type could give acceptable results unless the grain size of adopted TNT exceeds $400 \mu \mathrm{m}$, with its content in the final W/O explosive being $50 \% \mathrm{w} / \mathrm{w}$. Nevertheless, due to the wide variety of demilitarized ammunition objects it is impossible to attain a precisely defined quality level of demilitarized TNT. Thus the application of TNT in this sense would require simultaneous sensitization of final W/O mixture with micro-balloons. 
Application of demilitarized Composition B in similar way in the amount above $30 \% \mathrm{w} / \mathrm{w}$ of its content in W/O high explosive enables modification of detonation velocities of resulting emulsion mixtures within a broad range.

Relative performance ability (RS) of the W/O mixtures with added TNT is equivalent to the RPS of original W/O matrix that has been sensitized by addition of $3 \% \mathrm{w} / \mathrm{w}$ of microballoons. Even in the case of addition of Composition B, its effect upon relative performance ability is by far not as distinct as the effect on the detonation velocity. Irrespective of these facts, however, the addition of Composition B to the W/O matrix - in particular - can provide explosives for rock shooting and blasting, their performance being close to the performance values of industrial powdery amatols (e.g., the Czech Permonex v19 or Permon 10T) or some dynamites (Danubit), as the case may be; these industrial products exhibit relatively low detonation velocities. However, an addition of TNT to the W/O emulsion has no significant effect on the performance of resulting high explosive.

\section{References}

[1] Apolenis, A. V., Aleshkina, E. I., Annikov , V. E., Kozak, G. D., 2006. Explosion hazard of water gel-like systems on a base of high explosives, in: J. Ottis, M. Krupka (Eds.), Proceedings of the $9^{\text {th }}$ Seminar NTREM, University of Pardubice, pp. 464-472.

[2] Cook M. A. 1974. The science of industrial explosives. IRECO Chemicals, Salt Lake City, Utah.

[3] Elbeih, A.; Pachman, J.; Trzcinski, W. A.; Zeman, S.; Akstein, Z.; Selesovsky, J. 2011. Study of Plastic Explosives based on Attractive Cyclic Nitramines Part I. Detonation Characteristics of Explosives with C-4 Binder. Propellants, Explos., Pyrotech. 36: - in press.

[4] European Standard EN 13631-15, 2005. Explosives for civil use - High explosives Part 15: Calculation of the thermodynamic properties.

[5] Grys, S., Trzciński, W. A., 2010a. ZMWCyw - A code for calculations of thermodynamic properties of explosives for civil use according to a Standard PN-EN 13631-15, User's manual (in Polish), Warsaw.

[6] Grys, S., Trzciński, W. A., 2010b. Calculation of thermodynamic properties of explosives for civil use (in Polish), Przegląd Górniczy, 11, 118-125.

[7] Kohlíček, P., 2001. Detonation characteristics of the emulsion explosives, PhD. Thesis, Univ. of Pardubice.

[8] Kohlíček, P., Jakubček, E., Zeman, S., 2000. Some aspects of the application of small perforated powders in the emulsion explosives, in: O. Machacek (Ed.), Application of Demilitarized Gun and Rocket Propellants in Commercial Explosives, NATO Sci. Series II: Mathematical and Physical Chemistry - Vol. 3, Kluwer Acad. Publ. Dordrecht, pp. 59-71.

[9] Maranda, A., Lipińska, K., Lipiński, M., 2002. Analysis of possibility of waste energetic material application in mining blasting agents, Proceedings of the $5^{\text {th }}$ Seminar NTREM, University of Pardubice, pp. 146-150.

[10] Mendoca, M., Campos, J., Gois, J., 1996. Aqueous emulsion explosive with TNT. Proceedings of the $27^{\text {th }}$ International Annual Conference of ICT. Karlsruhe. pp. 56/1$56 / 13$. 
[11] Mendoca, M., Plaksin, I., Gois, J., 1997. Detonation behavior of emulsion explosive/TNT mixtures. Proceedings of the $28^{\text {th }}$ International Annual Conference of ICT. Karlsruhe, pp. 90/1-90/11.

[12] Němec, O., Novotný, M., Jungová, M., Zeman, S., 2011. Fortification of W/O Emulsions by Demilitarized Explosives. Central European Jurnal of Energetic Materials 8, 193-209

[13] Xuguang, W. Emulsion Explosives, Metallurgical Industry Press, Beijing, 1994

[14] Zeman, S., Kohlíček, P., Maranda, A., 2003. Study of chemical micro-mechanism governing detonation initiation of condensed explosive mixtures by means of differential thermal analysis. Thermochimica Acta, 398, 185-194.

[15] Zeman, S., Tamchyna, V., 2004. Applications of demilitarized energetic materials. Scientific Papers of the University of Pardubice, Faculty of Chemical Technology, Series A, 10, 271-277.

[16] Zeman, S., Tamchyna, V., 2005. Some applications of demilitarized energetic materials. In: R. Holmberg (Ed.), Third World Conference on Explosives \& Blasting Technique, EFEE, Brighton, pp. 499-503. 


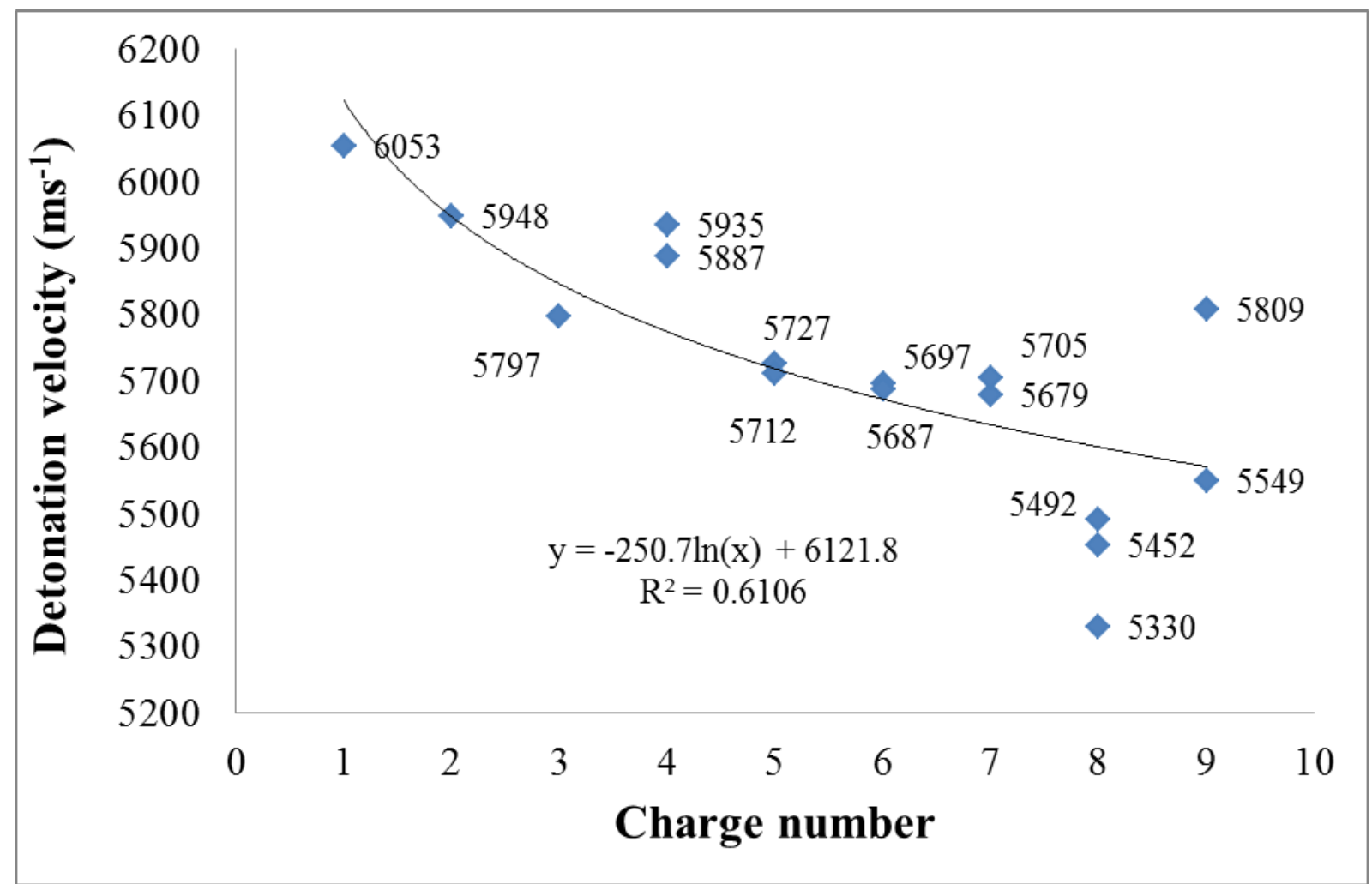

Fig. 1: Comparison of detonation velocities of mixtures of Emulsion matrix A (Table 5) with Politol of various grain size values (from $50 \mu \mathrm{m}$ to $4000 \mu \mathrm{m}$, Table 2) in 50/50 ratio

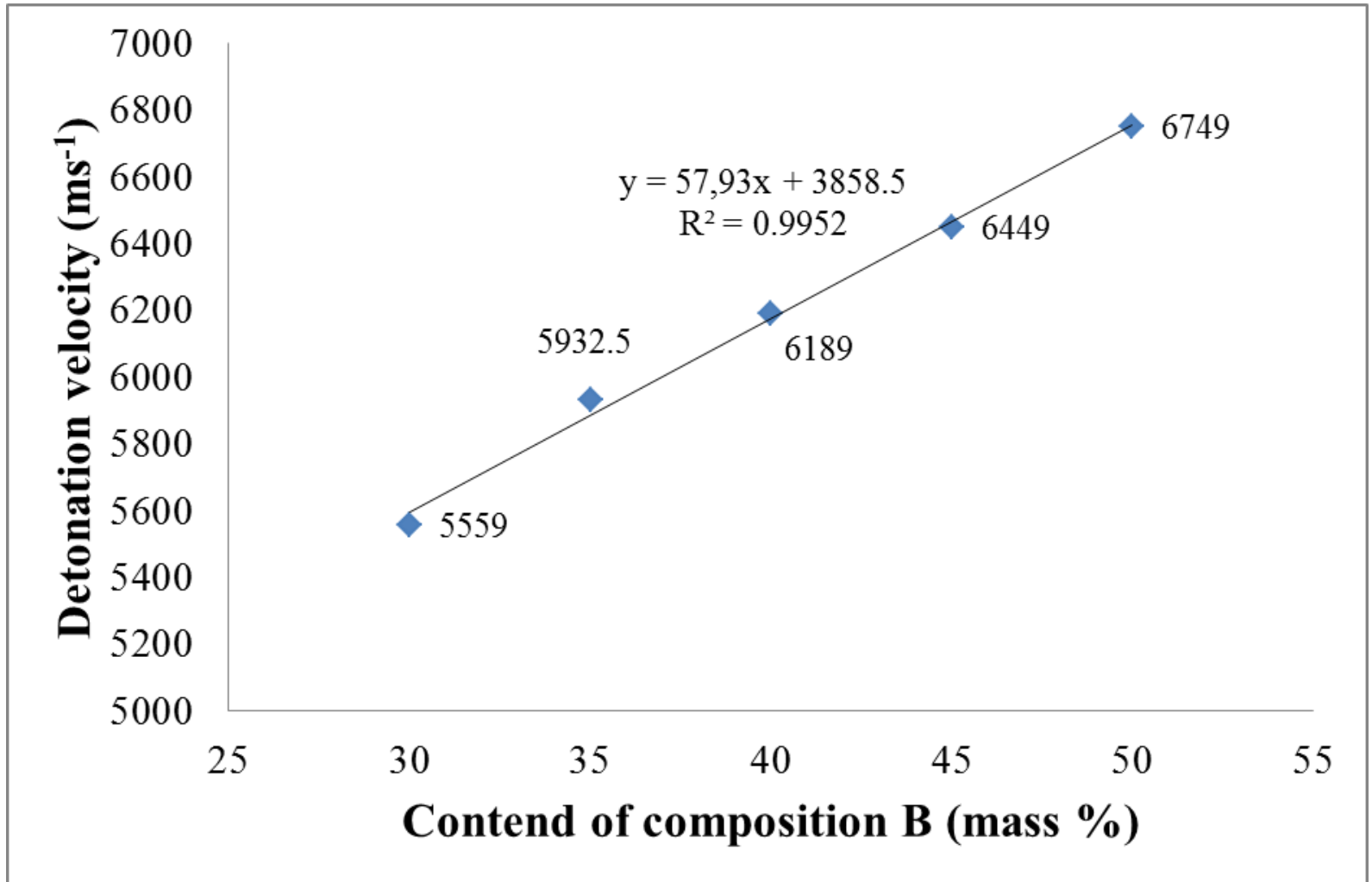

Fig. 2: Dependence of detonation velocity on content of unmodified demilitarized Composition B 


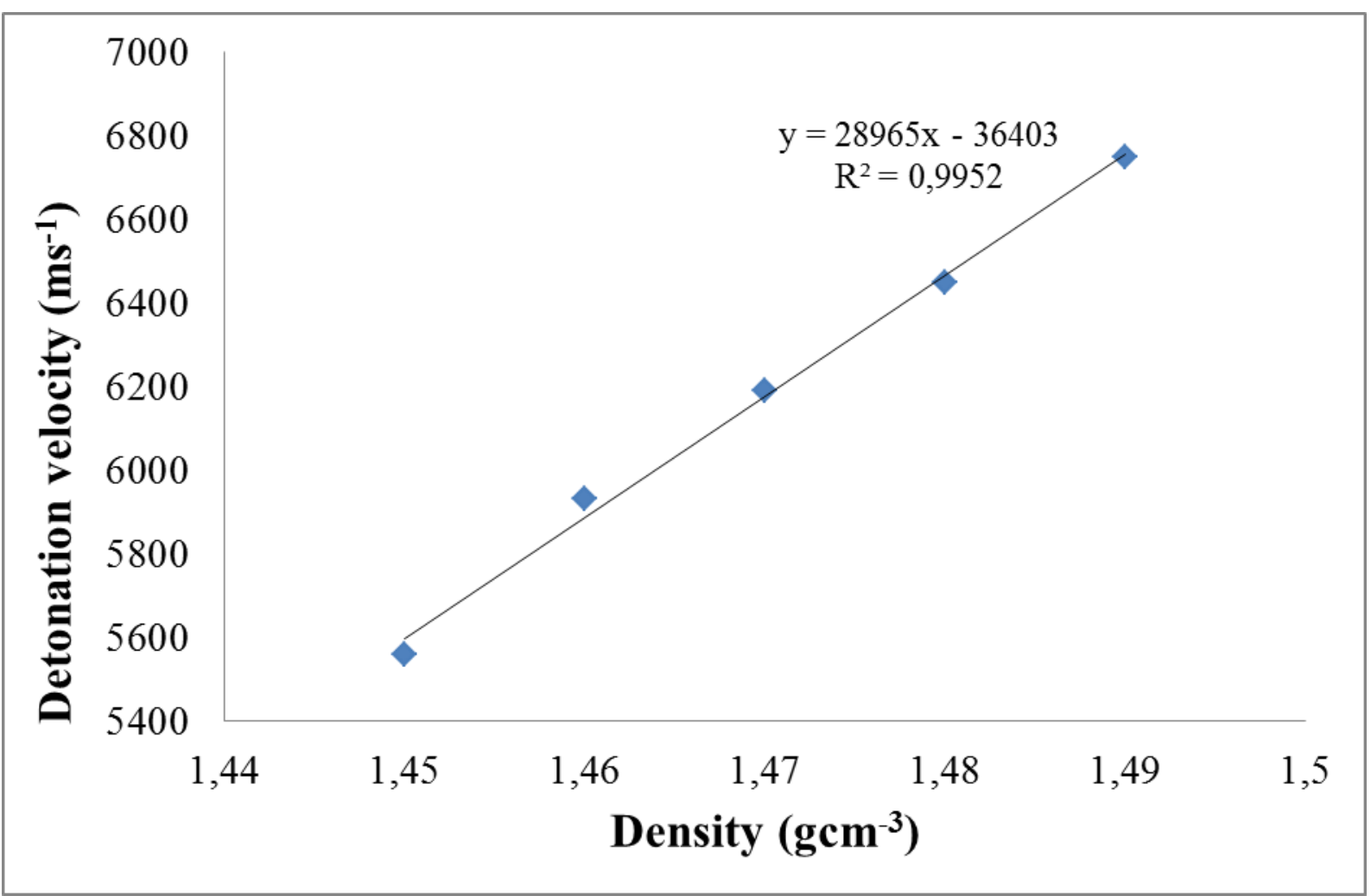

Fig. 3: Dependence of detonation velocity on density of mixture of Emulsion $\mathrm{A}$ and Composition B

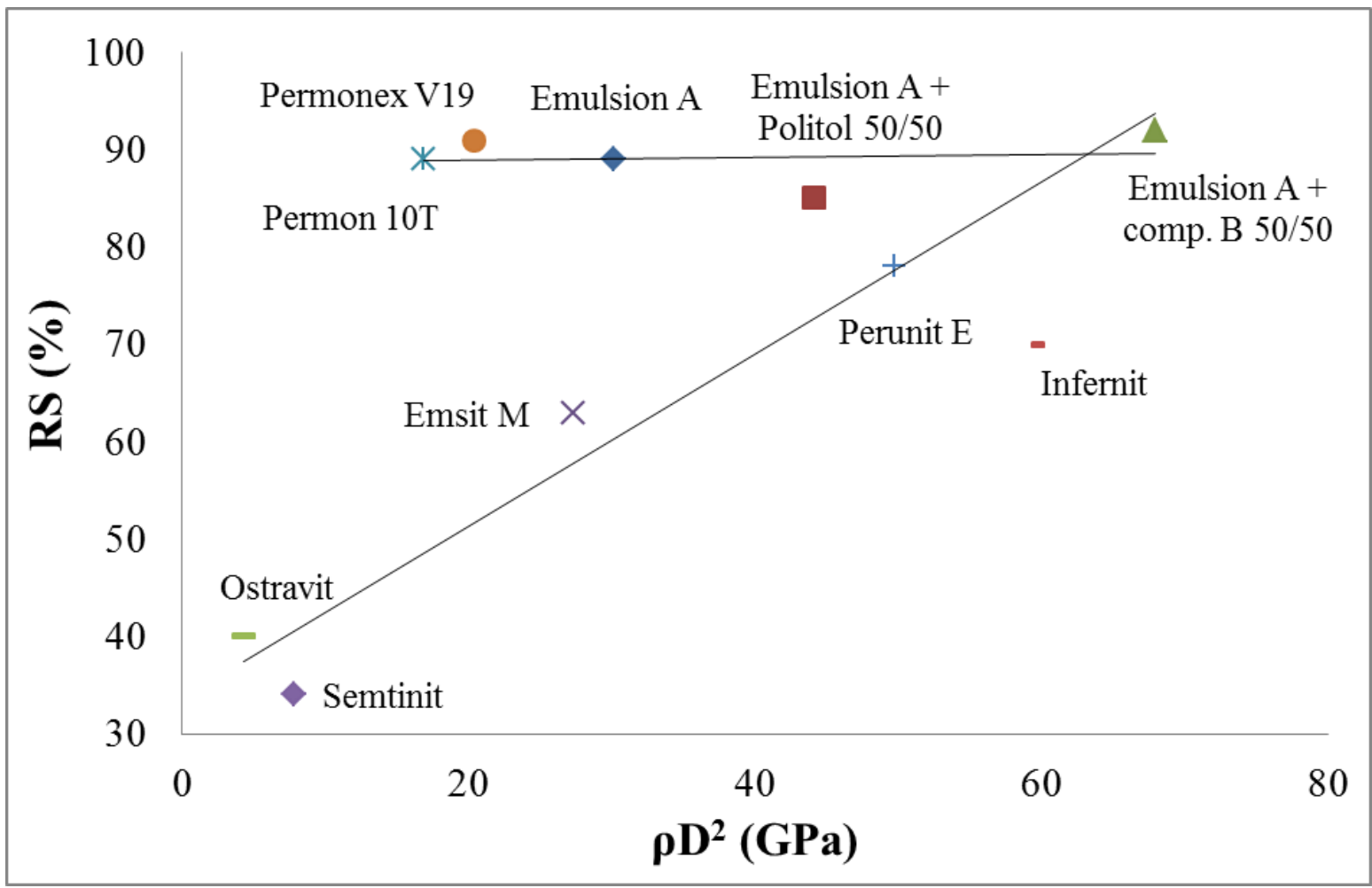

Fig. 4: Comparison of detonation parameters of commercially available high explosives manufactured by Explosia a.s. comp. with those of pure Emulsion A and mixtures of Emulsion A with brisant demilitarized high explosives 